\title{
BIOAKTIVITAS ANTIVIBRIOSIS DAN IDENTIFIKASI GOLONGAN SENYAWA PADA EKSTRAK YEAST DARI SEDIMEN EKOSISTEM MANGROVE KARIMUNJAWA
}

\author{
Sabrina Alisha Devi ${ }^{1}$, Wilis Ari Setyati ${ }^{1}$, Dyah Ayu Wulandary ${ }^{2}$, Ega \\ Saputra $^{2}$, Sakti Imam Muchlissin ${ }^{3}$ \\ ${ }^{1}$ Departemen IImu Kelautan Universitas Diponegoro Semarang \\ ${ }^{2}$ Departemen Akuakultur Universitas Diponegoro Semarang \\ ${ }^{3}$ Laboratorium Tropical Marine Biotechnology Universitas Diponegoro \\ Semarang \\ E-mail :wilisarisetyati@yahoo.co.id
}

Received August 2018, Accepted September 2018

\begin{abstract}
ABSTRAK
Yeast adalah mikroorganisme yang tidak dapat membentuk misellium. Tujuan dari penelitian ini untuk mengetahui aktivitas antibakteri dan mengidentifikasi golongan senyawa dari ekstrak yeast. Metode penelitian yang dilakukan antara lain 1). Sampling dan isolasi, 2). Kultur Massal, 3). Uji Bioassay dengan bakteri Vibrio harveyi dan Vibrio cholerae, (4). Analisis fitokimia, (5). Identifikasi Molekular menunjukkan bahwa isolat $\mathrm{KM}$ 3 memiliki kemiripan 99\% dengan Candida fermentati. KM 3 memiliki aktivitas antibakteri. Uji fitokim yang dilakukan mengidentifikasi golongan senyawa saponin, flavonoid, kuinon, tanin, alkaloid, steroid, dan triterpenoid.

Kata Kunci : Karimunjawa, Uji Fitokimia, Identifikasi Molekular, Candida fermentati

\section{ABSTRACT}

Yeast is a microorganism that can not create misellium. Aims of this study is to investigate antibacterial activity and to identify class of compounds from yeast extract. The methods of this study include 1). Sampling and isolation, 2). Mass Culture, 3). Bioassay Test with Vibrio harveyi and Vibrio cholerae, (4). Phytochemical analysis, (5). Molecular Identification showed that KM3 isolate has a 99\% similarity to Candida fermentati, KM 3 has antibacterial activity. Phytochemical tests were performed to identify classes of saponins, flavonoids, quinones, tannins, alkaloids, steroids, and triterpenoids.
\end{abstract}

Keywords : Karimunjawa, Phytochemical Analysis, Molecular Identification, Candida fermentati 


\section{PENDAHULUAN}

Bakteri Vibrio termasuk ke dalam bakteri gram negatif (Ananta WS et al., 2011). Vibrio cholerae dan Vibrio harveyi merupakan 2 jenis bakteri patogen yang paling banyak ditemui. Kedua jenis bakteri tersebut memiliki flagela di salah satu ujung polarnya. Vibrio cholerae tumbuh baik pada suasana basa $(\mathrm{pH} 8,0-9,5)$ dan dapat tumbuh dalam keadaan aerob dan anaerob. Pada media Thiosulphate Citrate Bile Salt (TCBS) koloni Vibrio harveyi berwarna putih sampai hijau dengan pusat koloni berwarna hijau tua (Utami et al., 2016). Karakteristik lain dari bakteri Vibrio harveyi yaitu bersifat patogen oportunistik, dimana jika kondisi lingkungan dan inangnya memburuk akan merubah sifatnya dari saprofitik menjadi patogenik (Widanarni et al., 2004).

Yeast atau yang biasa disebut dengan ragi adalah jamur yang tidak dapat membentuk miselium. Yeast biasanya diisolasi dari bahan bakar, air, tumbuhan, hewan dan serangga. Persediaan yeast di alam tidak sebanyak bakteri. Saat keadaan aerob maupun anaerob yeast tetap dapat tumbuh (Wina, 1999). Ukuran partikel yeast lebih besar dibandingkan dengan bakteri. Potensi yang dimilikinya untuk menghambat pertumbuhan bakteri serta resisten terhadap antibiotik dan sulfamid, dimana hal ini terjadi secara genetik. (Montes de Oca et al., 2016).

\section{MATERI DAN METODE}

\section{Metode Penelitian}

Metode yang dilakukan dalam penelitian ini yaitu metode penelitian eksperimen. Penelitian ini dilakukan di Laboratorium Tropical Marine Biotechnology, Fakultas Perikanan dan IImu Kelautan dan Laboratorium Terpadu Universitas Diponegoro, Semarang. Penelitian terdiri dari 5 tahap: 1). Sampling dan isolasi,2). Kultur Massal, 3). Uji Bioassay dengan Bakteri Vibrio harveyi dan Vibrio cholerae, (4). Analisis fitokimia, (5). Identifikasi Molekular.

\section{Lokasi Sampling dan Materi Penelitian}

Materi penelitian ini adalah sedimen Mangrove yang diperoleh dari Balai Taman Nasional Karimunjawa dan bakteri Vibrio harveyi dan Vibrio cholerae yang diperoleh dari koleksi Laboratorium Tropical Marine Biology Fakultas Perikanan dan Ilmu Kelautan Universitas Diponegoro, Semarang. Penelitian ini dilaksanakan pada Bulan April-Juli 2018.

\section{Isolasi dan Purifikasi Yeast}

Kegiatan penelitian dimulai dengan mengambil sampel sedimen mangrove dari Mangrove Tracking, Desa Kemojan, Karimunjawa. Sedimen dibawa ke Laboratorium dengan menggunakan Plastik Ziplock 
dan dimasukkan ke dalam Cool Box.Sampel sedimen mangrove sebanyak 0.2 gram dimasukkan kedalam Erlenmanyer dengan $20 \mathrm{ml}$ air laut steril ditambahkan serbuk sari pinus untuk menarik Yeast dengan Inkubasi 5-7 hari (Marchan et al., 2017).

\section{Uji Bioassay dengan Vibrio harveyi dan Vibrio Chlorela}

Metode Overlay (Radjasa, 2008) sebagai seleksi untuk mengetahui ada tidaknya potensi terbentuknya zona hambat. Isolat Yeast diambil dari sediaan di media miring dan dilakukan dotting pada media PDA serta diinbukasi selama 2x24 jam pada Inkubator. Isolat bakteri patogen ditanam pada media Nutrien Broth dengan Inkubasi $1 \times 24$ jam pada $5 \mathrm{~mL}$ di-shaker. Suspensi mikroba asosiasi diambil $0,5 \mathrm{~mL}$ (1\% dari total volume soft agar) dan dimasukkan ke dalam $50 \mathrm{~mL}$ media Nutrien Agar. Data hasil Overlay disajikan dalam bentuk tabel dengan informasi terbentuknya aktivitas zona hambat dinotasikan tanda plus (+) sedangkan tanda minus (-) menunjukkan bahwa tidak terbentuk zona hambat sehingga diperoleh data kualitatif.

\section{Kultur massa Yeast}

Isolat yang diperoleh dikultur dengan 2 media yang berbeda, pertama dengan media modifikasi menurut Burja et. al (2007) dengan komposisi Yeast extract 2g/L, Monosodium glutamate $8 \mathrm{~g} / \mathrm{L}$, Glukosa $20 \mathrm{~g} / \mathrm{L}$ serta media PYG cair menurut (Leano et. al, 2003) mycological peptone 1g/L, Yeast Extract 10g/L, Glukosa 10g/L. Isolat dikultur dengan bertingkat dari volume $5 \mathrm{ml}$ selama 1 hari, selanjutnya dipindahkan ke $45 \mathrm{ml}$, hingga pada media $200 \mathrm{ml}$. sehingga diperoleh total $250 \mathrm{ml}$ media cair yang berisi dengan kultur yeast.

\section{Uji Golongan Senyawa}

\section{(a) Saponin (uji busa)}

Ekstrak Yeast ditambahkan akuades dimasukkan ke dalam tube sebanyak $10 \mu \mathrm{l}$ dan dididihkan selama 5 menit kemudian digojok dengan vortex selama 10 detik. Ekstrak yang mengandung saponin ditandai dengan terbentuk busa yang tidak hilang selama 10 menit.

\section{(b) Flavonoid}

Ekstrak ditambahkan dengan aquades dimasukkan ke dalam tube sebanyak $10 \mu \mathrm{l}$ dengan ditambahkan $10 \mu \mathrm{l}$ serbuk $\mathrm{Mg}, 4 \mu \mathrm{HCl}$ dan $8 \mu \mathrm{l}$ amyl alcohol kemudian larutan digojog kuat dan biarkan hingga terpisah. Hasil positif apabila terbentuk warna kuning sampai merah pada lapisan amilalkohol (pada layer bagian atas). 


\section{(c) Kunion}

Ekstrak ditambahkan akuades dimasukkan kedalam tube sebanyak $10 \mu \mathrm{l}$ ditambah dengan Natrium Hidroksida $(\mathrm{NaOH}) 4 \mu \mathrm{l}$. Hasil positif terbentuk apabila terbentuk warna kuning

\section{(d) Tanin atau senyawa Fenolik}

Ekstrak ditambahkan akuades dan dimasukkan kedalam Cawan Porselin sebanyak $10 \mu \mathrm{l}$ ditambahkan larutan besi (III) Klorida (FeCl3) $1 \%$.

\section{(e) Alkaloid}

Ekstrak ditambahkan akuades dan dimasukkan kedalam Cawan Porselin sebanyak $10 \mu \mathrm{l}$ ditambahkan dengan pereaksi Dragendrof $20 \mu \mathrm{l}$. Terbentuk endapan coklat dapat teridentifikasi bahwa ekstrak mengandung senyawa alkaloid

\section{(f) Terpenoid dan steroid}

Kedua senyawa ini dapat dideteksi dengan menambahkan $10 \mu \mathrm{l}$ anhidrida asetat dan $5 \mu \mathrm{l} \mathrm{H} 2 \mathrm{SO}$. Reaksi bersifat positif mengandung senyawa terpenoid apabila menunjukan warna merah dan bersifat positif mengandung senyawa steroid apabila menunjukan warna biru.

\section{Identifikasi Molekular}

Ekstraksi Yeast menggunakan Metode Chelex (Lee, et al, 2006). Selanjutnya dilakukan tahap amplifikasi PCR menggunakan master mix Promega, pada komposisi Forward ITS 1 1ul, Reverse ITS 4 1ul, DNA Template 1 ul, Promega 12,5 ul, serta aquabides hingga volume total 25 ul. Proses PCR terdiri dari 35 siklus, yaitu pre-denaturasi pada $95^{\circ} \mathrm{C}$ selama 3 menit, Denaturasi pada $95^{\circ} \mathrm{C}$ selama 30 detik, Annealing pada $56,7^{\circ} \mathrm{C}$ selama 30 detik, ekstension pada $727^{\circ} \mathrm{C}$ selama 45 detik dan hold pada suhu $4^{\circ} \mathrm{C}$.

\section{HASIL DAN PEMBAHASAN}

\section{Uji Fitokimia}

Ekstrak yeast didapatkan dari 4 isolat dengan kode $\mathrm{T} 2, \mathrm{KM} 1, \mathrm{KM}$ 2, dan KM 3 yang berasal dari 2 media yaitu media PYG Broth dan MSG. Berat ekstrak yeast pada isolat T 2, KM 1, KM 2 dan KM 3 secara berturutturut sebanyak 2,9 mg, 3,7 mg, 5,1 mg,dan 22,4 mg pada media PYG 
Broth dan Pada media MSG sebanyak 31,6 mg, 26,4 mg, 15,4 mg dan 6,4 mg. Hasil ekstrak yang didapatkan melalui maserasi dan evaporasi. Hasil uji fitokimia dengan menggunakan media PYG Broth dan media MSG dapat dilihat pada Tabel 1 dan Tabel 2.

Tabel 1. Hasil uji fitokimia media PYG Broth

\begin{tabular}{lllll}
\hline Golongan & T2 & KM 1 & KM 2 & KM 3 \\
Senyawa & & & - & - \\
\hline Saponin & - & - & + & - \\
Flavanoid & + & - & + & - \\
Kuinon & + & - & + & + \\
Tanin & + & - & + & + \\
Alkanoid & + & - & - & - \\
Steroid & - & - & - & - \\
Triterpenoid & - & - & & \\
\hline
\end{tabular}

Tabel 2. Hasil uji fitokimia Media MSG

\begin{tabular}{lllll}
\hline $\begin{array}{l}\text { Golongan } \\
\text { Senyawa }\end{array}$ & T2 & KM 1 & KM 2 & KM 3 \\
\hline Saponin & + & - & - & + \\
Flavanoid & - & - & - & + \\
Kuinon & - & + & + & + \\
Tanin & + & + & + & + \\
Alkanoid & + & + & + & + \\
Steroid & - & - & - & - \\
Triterpenoid & - & - & - & - \\
\hline
\end{tabular}

Menurut Sangi et al, (2008), Penentuan kandungan kimia dilakukan melalui analisis fitokimia secara kualitatif. Analisis fitokimia secara kualitatif ini merupakan suatu metode analisis awal untuk meneliti kandungan senyawa-senyawa kimia. Ekstraksi dari sedimen mangrove pada uji fitokimia dengan media PYG broth pada golongan saponin, steroid dan triterpenoid didapatkan hasil negatif pada semua sampel, pada golongan flavonoid dan kuinon sampel T2 dan KM2 hasilnya positif flavonoid merupakan senyawa fenolik diketahui memiliki aktivitas antibakteri menurut Mohamad et al (2012), flavonoid memiliki sifat lipofilik yang dapat menghancurkan dinding sel bakteri dan menurut Nuraini (2007) yang menyatakan bahwa golongan flavonoid dan tanin memiliki aktivitas antibakteri. Golongan senyawa tanin dan Alkaloid T2, KM2, dan KM3 hasilnya positif. Alkaloid adalah senyawa metabolit sekunder terbanyak yang memiliki atom nitrogen, yang ditemukan dalam jaringan tumbuhan dan hewan. Sebagian besar senyawa alkaloid bersumber dari tumbuh-tumbuhan, terutama angiosperm. Lebih dari 20\% spesies angiosperm mengandung alkaloid (Wink, 2008). 
Hasil dari ekstraksi dari sedimen mangrove pada uji fitokimia dengan media MSG pada golongan senyawa saponin didapatkan hasil positif pada T2 dan KM3, pada golongan senyawa flavonoid positif pada $\mathrm{KM} 3$, hasil dari kuinon positif pada sampel KM1, KM2, dan KM3; pada tanin dan alkaloid postif pada semua sampel; sedangkan pada steroid dan triterpenoid hasilnya negatif pada semua sampel.

\section{Uji Bioassay Antibakteri}

Uji Bioassay antibakteri pada 4 isolat Yeast dengan bakteri uji Vibrio harveyi dan Vibrio cholerae menunjukkan hasil positif hanya pada sampel KM3 yang mampu membentuk zona hambat (lihat Tabel 3).

Tabel 3. Uji Bioassay Antibakteri

\begin{tabular}{lcccc}
\hline Bakteri Uji & T2 & KM 1 & KM 2 & KM 3 \\
\hline $\begin{array}{l}\text { Vibrio harveyi } \\
\begin{array}{l}\text { Vibrio } \\
\text { cholerae }\end{array}\end{array}$ & - & - & - & + \\
\hline
\end{tabular}

Penanaman bakteri pada media dengan teknik penggoresan bertujuan untuk mendapatkan bakteri yang murni dan digunakan dalam uji aktivitas antibakteri (Riyanto et al, 2013).

\section{Identifikasi Molekuler}

Hasil identifikasi molekuler dapat dilihat pada Tabel 4.

Tabel 4. Identifikasi Molekuler

\begin{tabular}{|c|c|c|c|c|}
\hline $\begin{array}{l}\text { Kode } \\
\text { Isolat }\end{array}$ & $\begin{array}{l}\text { Panjang } \\
\text { Basanukleotida }\end{array}$ & $\begin{array}{l}\text { Kedekatan } \\
\text { Spesies }\end{array}$ & $\begin{array}{l}\text { Persen } \\
\text { Kemiripan }\end{array}$ & $\begin{array}{l}\text { Accession } \\
\text { Number }\end{array}$ \\
\hline KM 3 & 612 & $\begin{array}{l}\text { Meyerozyma } \\
\text { caribbica } \\
\text { (Candida } \\
\text { fermentati) }\end{array}$ & $99 \%$ & KM402049 \\
\hline
\end{tabular}

Hasil identifikasi molekuler diperoleh bahwa isolat KM 3 memiliki kedekatan dengan Candida fermentati dengan kemiripan $99 \%$.

\section{KESIMPULAN}

Hasil penelitian yang didapatkan adalah pada uji fitokima pada pada media PYG Broth golongan saponin, steroid dan triterpenoid didapatkan hasil negatif pada semua sampel, pada golongan flavonoid dan kuinon sampel T2 dan KM2 positif, Golongan senyawa tanin dan Alkaloid T2, KM2, dan KM3 hasilnya positif. Sedangkan pada media MSG 
golongan senyawa saponin didapatkan hasil positif pada T2 dan KM3, senyawa flavonoid positif pada KM3, senyawa kuinon positif pada sampel $\mathrm{KM} 1, \mathrm{KM} 2$, dan KM3; senyawa tanin dan alkaloid postif pada semua sampel; sedangkan pada steroid dan triterpenoid hasilnya negatif pada semua sampel. Uji aktivitas antibakteri terdapat zona bening pada isolat dengan kode KM3 dengan nama spesies Candida fermentati.

\section{UCAPAN TERIMA KASIH}

Penulis mengucapkan Terima kasih kepada Kementerian Riset dan Teknologi dan Pendidikan Tinggi (KEMRISTEKDIKTI) dalam program Program Kreativitas Mahasiswa PKM yang telah memberikan dana penelitian. Semua teman-teman dan staf Laboratorium Tropical Marine Biotechnology, FPIK Undip yang telah membantu jalannnya dan kelancaran penelitian ini.

\section{DAFTAR PUSTAKA}

Ananta WS, I P, IGM Wijaya P., IGP Dhinarananta, P. Yuniadi A. Dan M. Agus Hendrayana. 2011. Identifikasi Serotipe Bakteri Vibrio cholerae Terisolasi dari Es Bahan Pengawet Ikan Yang Digunakan Oleh Pedagang Hasil Laut Pasar Modern dan Pasar Tradisional di Kota Denpasar.

Burja, A. M., Armenta, R. E., Radianingtyas, Helia, Barrow C. J. 2007. Evalution of Fatty acid Extraction Methods for Thraustochytrium sp. ONC-T18. J. Agric. Food Chem. 2007,554795-4801.

Leano, E. M., Gapasin, R. S..J., Polohan, Bernice, Vrijmoed, L.L.P., 2003. Growth and Fatty Acid Production of Thraustochytrids from Panay Mangroves Philippines. Fungal Diversity.

Lee, Y. K., Hyun Jung Jung and Hong Kum Lee. 2006. Marine Bacteria Associated with The Korean Brown Alga, Unidaria pinnatifida. The Journal of Microbiology, 44 (6): 694-698.

Marchan, Loris Fossier, K. J. L. Chang, P. D. Nichols, J. L. Polglase, W. J. Mitchell, and T. Gutierrez. 2017. Screening of New British Thraustochytrids Isolates for Docosahexaenoic Acid (DHA) Production. Journal of Applied Phycology. 1-13.

Mohamad R,Widyastuti, Suradikusumah, dan Darusman. 2012. Aktivitas Antioksidan, Kadar Fenol, dan Flavonoid Total dari Enam Tumbuhan Obat Indonesia. Tradd. Med. J. Vol 18:29-34. 
Montes de Oca, R., Salem, A.Z.M., Kholif, A.E., Monroy, H., Pérez L.S., Zamora, J.L. and Gutiérez, A. 2016. Yeast: Description and Structure.

Nuraini AD. 2007. Ekstraksi Komponen Antibakteri dan Antioksidan dari Biji Teratai (Nymohaea pubescens Willd) [Skripsi]. Bogor: Institut Pertanian Bogor.

Radjasa, O. K. 2008. Growth Inhibition of Medically Antibiotic Resistant Bacteria by Sponge-Associated Bacteria. Journal of Coastal Development, 11 (2): 75-80.

RiyantoE.I., I. Widowati dan A. Sabdono.2013. Skrining Aktivitas Antibakteri Pada Ekstrak Sargassum polycystum Terhadap Bakteri Vibrio harveyi dan Micrococcus luteus Di Pulau Panjang Jepara. Skrining Aktivitas Antibakteri Pada Ekstrak Sargassum polycystum Terhadap Bakteri Vibrio harveyi dan Micrococcus luteus Di Pulau Panjang Jepara.

Sangi, M., M. R. J. Runtuwene, Herny E. I. Simbala dan Veronica M. A. Makang. 2008. Analisis Fitokimia Tumbuhan Obat Di Kabupaten Minahasa Utara. Chem. Prog. 1(1) : 47-53.

Utami, W, Sarjito dan Desrina. 2016. Pengaruh Salinitas Terhadap Efek Infeksi Vibrio harveyi Pada Udang Vaname (Litopenaeus vannamei). Journal of Aquaculture Management and Technology. 5(1): $82-90$.

Widanarni, D. Meha, S. Nuryati, Sukenda dan A. Suwanto. 2004. Uji Patogenisitas Vibrio harveyi Pada Larva Udang Windu Mengguna; 23kan Resisten Rifampisin sebagai Penanda Molekuler. Jurnal Akuakultur Indonesia. 3(3): $23-27$.

Wina, E. 1999. Pemanfaatan Ragi (Yeast) sebagai Pakan Imbuhan Untuk Meningkatkan Produktivitas Ternak Ruminansia. WARTAZOA. 9(2): $1-8$.

Wink, M. (2008). Ecological Roles of Alkaloids. Wink, M. (Eds.)Modern Alkaloids, Structure, Isolation Synthesis and Biology,Wiley, Jerman: Wiley-VCH Verlag GmbH \& Co. KgaA. 